\title{
The Hindu as Other: State, Law, and Land Relations in Contemporary Bangladesh
}

Shelley Feldman

\section{OpenEdition}

\section{Journals}

\section{Electronic version}

URL: http://journals.openedition.org/samaj/4111

DOI: $10.4000 /$ samaj.4111

ISSN: $1960-6060$

\section{Publisher}

Association pour la recherche sur l'Asie du Sud (ARAS)

\section{Electronic reference}

Shelley Feldman, «The Hindu as Other: State, Law, and Land Relations in Contemporary Bangladesh », South Asia Multidisciplinary Academic Journal [Online], 13 | 2016, Online since 08 March 2016, connection on 19 April 2019. URL : http://journals.openedition.org/samaj/4111 ; DOI : 10.4000/ samaj. 4111

This text was automatically generated on 19 April 2019

\section{$(1) \Theta \Theta$}

This work is licensed under a Creative Commons Attribution-NonCommercial-NoDerivatives 4.0 International License. 


\title{
The Hindu as Other: State, Law, and Land Relations in Contemporary Bangladesh
}

\author{
Shelley Feldman
}

\begin{abstract}
Depeasantization and victimization are active elements in the process of [exclusion,] [...] Not only

[are] the Muslim peasants depeasantized, pauperized and lumpenized on their arrival in India, the Hindu peasantry of Bangladesh is cynically and most systematically robbed of land on communal considerations in the villages of Bangladesh and this [results in] peasants [...] [being] forced to flee. The catalyst in this case is the enemy (vested) property laws (Trivedi 2007).
\end{abstract}

\section{Introduction}

1 In this paper, I argue that the Enemy or Vested Property Act (VPA $)^{1}$ and its multiple reforms provide a window into on the construction of Hindu citizens of Bangladesh as Other. I draw particular attention to the regimes in power since 1971 for what they reveal about the reproduction of a minority population, since the country is premised on democratic principles of equality among citizens. In so doing, I expose the paradox that resides in the relationship between the genocidal struggle for independence and secularism and a presumed ethnic, rather than religious, basis for belonging. I suggest that the construction of Hindus as the other legitimates state appropriations ${ }^{2}$ of their property and, by challenging their rights to land ownership as a right of all citizens, constructs Hindus as a threat to national security. This construction legitimates land appropriation in the interest of state needs, as well as for private accumulation. It finds a parallel in Ayesha Jalal's suggestion of a significant feature legitimating the offensive position of Pakistan during the independence struggle: 'If Hindu India is the enemy 
without, the proponents of regional autonomy alongside the ungodly secularists ${ }^{3}$ are the enemies within' (Jalal 1995: 82).

To explore these themes, I draw on interviews conducted during three periods of fieldwork, in 2013 in Rajshahi, a northern district of Bangladesh, and in 2014 in Dhaka, as well as over the course of numerous field trips in Bangladesh during earlier stays in the country. I also draw on lengthy discussions with a key informant, a scholar from Bangladesh temporarily in the U.S. Finally, the argument builds on cases examined from the Dacca (subsequently Dhaka) Law Review, 1960-2011, although it does not focus on particular cases, and an exploration of newspaper reports that are critical for signalling recent public expressions of violence against Hindus. The discussion unfolds first by examining land appropriation as a relation of subjection. This is followed by an examination of the making of majoritarian rule, both before and after independence, including a focus on the current conjuncture about what it portends for property relations and the differential rights of Bangladeshi citizens. The principal purpose of the paper, however, is not to offer new evidence on land appropriation. Rather, I provide a new interpretation of extant evidence, one that moves from structuralist accounts that contribute to our understanding of accumulation practices, to an argument for the inseparability of accumulation practices in/as a relation of rule and subjection. In other words, I argue that distinct from studies that view subjection as a response to structural and political change, these processes are relational and co-constitutive. I also show that marking people as the other from whom property appropriations could be justified was not an outcome of a single policy, fixed once and for all, but, instead, a set of ongoing and contradictory policy reforms and practices that reproduce both difference and majoritarian rule.

\section{Land appropriation as a relation of subjection}

Debates focused on land grabbing, including both large-scale appropriations by governments as well as everyday takings from small producers, have renewed interest in Marx's conception of 'so-called primitive accumulation' understood as the enclosure of private land holdings and the separation of direct producers from their means of subsistence and production. ${ }^{4}$ These debates have opened to scrutiny the character of accumulation processes, as well as their costs for particular constituencies who are most often the poor and unprotected. The basis of these debates is Marx's understanding of primitive accumulation that transforms the social means of subsistence and of production into capital [and] the immediate producers into wage labourers' (Marx 1983: 668).

4 Crucially, Marx presupposes 'the complete separation of labourers from all property in the means by which they can realize their labour' as the basis of capitalism. Debate continues, however, as to whether this separation or 'historical premise' refers solely to the original appropriation or to an ongoing process of social transformation. As Marx maintains:

As soon as capitalist production is once on its own legs, it not only maintains this separation, but reproduces it on a continually extending scale. The process, therefore, that clears the way for capitalist production, can be none other than the process which takes away from the labourer the possession of his means of production (Marx 1983: 668, emphasis added). 
5 Two points are significant for the discussion to follow. One is that the appropriation of land is central to the reorganization of capitalist agriculture and, hence, to processes of accumulation. This builds on the assumption that meeting the world's food needs requires increasingly large-scale commercial agricultural production that can no longer be accommodated under the mix of large, medium, subsistence, and under-subsistence producers. This assumption, and declining support for small-scale agricultural producers, sets the conditions for the consolidation of landholdings. This assumption is part of a neoliberal development strategy that supports investment in non-farm work, credit, and micro-enterprise development under the premise that wage labour is better able than agriculture to meet the reproduction needs of small-scale producers. ${ }^{5}$ Second, and following from the separation of people from their productive resources, is the need to continually reproduce this separation through both direct and indirect property appropriations. Together, these processes enable ongoing, if historically contingent, relations of accumulation. Further, tethering land appropriation and the commodification of labour power produces particular subjectivities, since how people make a life through work and social reproduction casts them in relation to each other, to their communities as sites marked by specific senses of security and responsibility, and to the constitution of a national imaginary that shapes identification, identity, and belonging. ${ }^{6}$

6 Following S. Charusheela (2011: 323), I engage the connection between land appropriation and the violent establishment 'of the conditions for the subjugation and subjective emergence of the wage labourer', a relation that is particularly suggestive in examining contemporary land relations in Bangladesh, with three critical qualifications. First, unlike the need to release labour to support a large and emergent labour market that explained the first so-called primitive accumulation, today the expropriation of people from their property 'release[s] a set of assets (including labour power) at very low (and in some instances zero) cost. Over-accumulated capital can seize hold of such assets and immediately turn them to profitable use' (Harvey 2003: 149). This expropriation, often by private capital, has transformed the landscape in the areas around Bangladeshi cities, particularly Dhaka, as agricultural land becomes the ground for both industrial production and residential communities. Under eminent domain, the state has also seized large tracts of peri-urban land for military housing.

7 A second qualification of Charusheela's contribution concerns the people from whom private property can be confiscated. To be sure, the category of the poor is highly differentiated in ways that lead one to ask: From whom, among the vulnerable, can land or property grabs be legitimated without sparking broad-based reprisal? What context shapes identification of this constituency, and precisely how are property and resource grabs justified and enacted based upon the specificity of a group's identity? These questions raise the third qualification of Charusheela's suggestive intervention, the importance of understanding relations of rule and the constitutive character of belonging, identification, and national identity for policy reform. Focusing on this constitutive process draws attention to how institutional, bureaucratic, and governance practices shape the ways in which rule is enacted. It also draws attention to how building legitimacy, as the substance of rulemaking, aids in establishing who belongs and who is marginalized or excluded, who has rights, and whose rights can be compromised without fear of public outrage. Included in this process is what Philip Abrams (1988: 61) understands as the building of hegemony, constituted by institutional and discursive 
practices that are often enshrined in law, embedded in the 'public aspects of politics' (Abrams 188: 61), and routinized in symbolic gestures and moral judgments. These processes provide the ground for patterns of social inclusion/exclusion, ${ }^{7}$ ethnicization, ${ }^{8}$ and minoritization, ${ }^{9}$ which produce communities in a hierarchy of economic and social security positioned in relation to their rights and ability to demand legal accountability. In examining these relations of othering, I ask the following questions: How do the social relations that embody land and property appropriations, notorious for their enactment through 'conquest, enslavement, robbery, murder, and in short, force, [which] plays the greatest part' (Marx 1983: 668), help to create particular kinds of subjects? What role does policy and governance, including claims of national interest and security play in legitimating land appropriation? What, for example, is the role of bureaucratic elites in facilitating and securing land grabs through violent, as well as non-violent, means? Finally, how do rhetorics of othering secure the legitimacy of dispossession among minority populations? Responses to these questions will expose the mutually constitutive character of relations of accumulation and subjection.

9 As a predatory political formation, Bangladesh's so-called democracy includes universal suffrage and free and fair elections. As popularly understood, however, the political process consists of competition over which party will benefit from the 'unethical but, nevertheless, socially accepted' struggle over state resources and privileges, including exploitation of the environment and extractive and natural resources (Pertev 2009: 9). A variant of crony capitalism, these predations entail illegal appropriations that further the control and concentration of scarce resources that can be leveraged for state patronage, as well as for private gain. But importantly, such appropriations are not usually directed at an undifferentiated vulnerable population. Rather, such seizures target particular populations through practices that are legitimated in state rule. This is precisely the case in Bangladesh, where Hindu citizens have been subjected to property appropriations legitimized by the Enemy/Vested Property Act, established specifically to justify land enclosures of their property. The result is the constitution of forms of rule and subjection that are best understood as both the process and product of the construction of the Hindu as other.

\section{The Vested Property Act (VPA) and the making of majoritarian rule: the East Pakistan period}

Following the 1947 partition of India into the predominantly Muslim state of Pakistan, including its East and West Wings, and the Hindu majority state of India, Mohammad Ali Jinnah, the founder and first governor general of Pakistan, initially repudiated the theocratic foundations of the Pakistani state, noting that, 'You may belong to any religion or caste or creed. That has nothing to do with the business of the state. We are starting with this fundamental principle that we are all citizens and equal citizens of the state' (Jinnah 2004). But despite this proclamation, he soon thereafter attempted to build a nationalist project in an idiom of a shared Urdu language, ostensibly to create a sense of collective belonging that would bring the East and West Wings together. The argument against Bengali, and for Urdu, was that Bengali did not comport with the construction of a national narrative articulated in the sacralized language and cultural traditions of Islam. At this time, the Hindu population was estimated to be between 10 and 12 million with Muslims accounting for 32 million (Lambert 1950, Schechtman 1951). Thus, 
introducing Urdu as the lingua franca was a response to the perceived threat of Bengali nationalism in the East, where Bengali language and culture were infused with Hindu religious and linguistic idioms, and a significant proportion of the population was Hindu. This language initiative can thus be understood as an effort to mark Hindus as a community distinct from East Bengal's Muslim majority.

11 In addition to the 1948 struggle against Urdu, the 1949 effort to introduce the Arabic script instead of the Sanskritized Devanagari Bengali script, led to the Language Movement-bhasha andolan-in East Pakistan. The Movement sought recognition of the East as a multi-religious community whose mark of national belonging was shared language rather than religious identity. ${ }^{10,11} \mathrm{~A}$ bloody battle ensued following a five-year struggle against the imposition of Urdu as the lingua franca. A number of university students were killed and today, for many Bengalis, Hindus and Muslims alike, Ekushy, 21 February, remains a hallmark of national pride.

12 Struggles over recognition of the multiethnic character of East Pakistan, and the particular place of Hindus in the body politic, also included the State's proposal for a separate electorate for minorities. But Bengali Muslims and Hindus alike rejected this proposal, even as a 1956 Constitutional provision only allowed Muslims to serve as the president of Pakistan. Arguing against the proposal were Basant Kumar Das, Peter Paul Gomez and B.K. Dutta, as well as H.S. Suhrawardy and Mujib-ur-Rahman, ${ }^{12}$ all members of the Constituent Assembly that included Hindus, Christians, and Muslims. They claimed that the proposal would relegate minorities to the status of second-class citizens and, significantly, would put Muslims residing in India at risk, since the politics of the period reflected an implicit or explicit engagement with policies in India.

Passage of The East Bengal (Emergency) Requisition of Property Act (XIII of 1948) ${ }^{13}$ was Jinnah's final action aimed at marking Hindus as second-class citizens. The Act empowered the government to 'acquire, either on a temporary or permanent basis, any property it considered needful for the administration of the state' (Barkat et al. 1997: 27). Although claimed to be necessary to meet the administrative needs of the newly independent province, including the need to accommodate government offices and civil servants, it also obfuscated illegal appropriations, particularly of Hindus (Mohsin 2004). According to Lambert (1950), '80 percent of the urban property in East Bengal was in the hands of Hindus', as were large estates. The value of real property and other assets assumed abandoned in East Pakistan 'was officially estimated by the Chief Minister of West Bengal at 870 million rupees (US\$182,700,000)' (Schechtman 1951: 412). Such unequal ownership of property helped to publically justify state confiscations without compensation.

Thus, in theory, the agreement signed by Prime Ministers Liaquat Ali Khan of Pakistan, and Jawaharlal Nehru of India on 10 April 1950, provided a hopeful sign for migrants, as it acknowledged that refugees would be permitted to take with them their movable personal effects, including up to 150 rupees. It further acknowledged that immovable property would not be confiscated, even if occupied by another person, if its owner returned to East Pakistan before the end of 1950. If, however, landowners chose not to return, they were free to either sell or exchange their property (Schechtman 1951: 412). Significantly, the agreement promised that '[r]ent or compensation for requisitioned property was to be promptly assessed and paid over to the owner' (Schechtman 1951: 412). In practice, however, these Acts instead dispossessed Hindus who opted for Pakistan 
and instantiated a long, and still ongoing, process that reproduced religious difference as central to the project of Pakistani state- and nation-making.

The India-Pakistan War in 1965 also legitimated relations of Hindu othering by providing the state with an opportunity to reiterate the criticality of Muslim unity in Pakistan and to mark Hindus as potential threats to this unity. This short war also legitimated President Ayub Khan's passing of Order XXIII of 1965, The Defense of Pakistan Ordinance, declaring India an enemy country and authorizing the confiscation of all interests of the enemy. ${ }^{14}$ This 'undisguised act of retaliation', (Benkin 2009: 79) included taking possession of property from those who were citizens of India but also citizens of territories in which Hindus, now proclaimed as the enemy, resided, occupied, controlled, or were captured. The conflation of India with all Hindus in undivided India justified Ayub Khan's passage of the Ordinance with the Enemy Property (Custody and Registration) Order of 1965 and 1966, and the East Pakistan Enemy Property (Lands and Buildings) Administration and Disposal Order, 1966, under Rule 182 (1) of the Defense of Pakistan Rule. Together, both Ordinances reconfirmed in law the Hindu as other, thus framing the national narrative in an idiom of Islam.

Despite revoking the state of emergency on 16 February 1969, The Defense of Pakistan Rules relating to the control of trade with the enemy and their firms continued, as did use of the term 'enemy'. This continuance empowered the District Commissioners, who held bureaucratic control in the rural areas, to implement these ordinances and rules under the Government's declaration of the Enemy Property, Continuance of Emergency Provisions Ordinance, 1969 (Ordinance I of 1969), even in the absence of war (Barkat et al. 2008).

17 Shrouded in claims of national security, together these orders imposed draconian rules aimed at Hindu landowners and those owning firms and buildings that sanctioned property acquisition by the state (Shafi 2007, Mohsin 2004). The enemy, couched in an idiom of state security, included all Hindus who resided in India, even if they had family or kin in Pakistan and who, according to Hindu inheritance law, could be the recipients of their property (Barkat et al. 1997). Thus, declaring India an enemy state meant that even Hindus living in East Pakistan were included among those whose allegiance was suspect and assumed to be inevitably tied to India. It led, as well, to a second major displacement, since Hindus were now deprived of their rights to property and to its transfer, sale, and gifting.

18 Despite these takings, Hindus continued to opt for East Pakistan as their country of belonging, a choice that valorized its syncretic tradition, language, and the identification of the majority of its inhabitants as Bengali rather than Muslim. Those Hindus remaining in the East, however, challenged the leadership in the West, who feared their potential electoral power and their progressive orientation, and viewed their decision as a threat to national security. These challenges eventually helped catalyse the West Pakistan response to the East Wing's call for autonomy-the threat of Bengali nationalism and a questionable identification with Islam, stemming, in some measure, from the haunting success of the Language Movement and the struggle against Urdu as the national language. 


\section{Reproducing majoritarian rule: the politics of independence}

19 Paradoxically, recognizing the syncretism that defined what was distinctive about Bengali cultural practices provided not only a marked other for the West but also the grounds for the secular demands that would shape the movement for an independent Bangladesh. This claim acknowledges that, following the Indo-Pakistan war, there was a growing demand for political and economic autonomy of the East Wing. This was especially so following Army Chief Yahya Khan's passing of the Enemy Property (Continuance of Emergency Provision) Ordinance in 1969, which, by declaring martial law, annulled the Constitution that recognized the fundamental right to 'profess any religion'. This militarization of the region sustained state efforts to eliminate from the East any association with the region's Hindu past and to control progressive elements that sought regional autonomy. Notable here is not only Khan's refusal to address Sheik Mujibur Rahman's initial demand for the autonomy of East Pakistan-and, eventually, an independent Bangladesh-but also his ordering of military intervention to suppress the Awami League, as well as to curtail political mobilization. Rather than negotiate for autonomy, the military entered East Pakistan, targeting Hindus and progressive forces in one of the most brutal genocides in world history.

Hindu faculty at Dhaka University were among the first assassinated by the Pakistan army during Operation Searchlight on 26 March 1971, as they, and other progressive faculty, were assumed to have instigated the movement for autonomy. The military was particularly hostile to Hindus-who, they believed, 'played a malevolent role in East Bengal',-given their assumption that Hindus were 'natural' inhabitants of India and, thus, were intent on either exterminating or driving them out of the country (Beachler 2007: 467). As van Schendel (2009: 162) wrote:

In these first gruesome hours of army terror, people all over Dhaka were picked up from their homes and 'dispatched to Bangladesh'-the army's euphemism for summary execution. There were verbal and later written orders to shoot Hindu citizens. Dhaka's old artisan neighborhood of Shankharipotti [...] was attacked and Hindu inhabitants murdered. Many prominent Hindus were sought out and put to death.

US Senator Edward Kennedy likewise remarked about the targeting of Hindus during the independence war:

Field reports to the US Government, countless eye-witnesses, journalistic accounts, reports of international agencies [...] document the reign of terror which grips East Bengal (East Pakistan). Hardest hit have been members of the Hindu community who have been robbed of their lands and shops, systematically slaughtered, and in some cases, painted with yellow patches marked ' $\mathrm{H}$ '. All of this has been officially sanctioned, ordered and implemented under martial law from Islamabad (Lintner 2003: 2).

The result of this reign of terror was another mass migration of Hindu East Pakistanis to India, signaling the complex identifications shaping the lives of those who chose to remain in the country. ${ }^{15}$

This targeting of Hindus institutionalized the right to violence that can turn neighbors into enemies and people to be feared for the threat they pose to conceptions of national belonging. It also can destroy community and forms of sociality that make such behavior 
against kin or neighbor possible. Paradoxically, this construction of the Hindu as other became most evident when, on 10 April 1971, after declaring liberation on 26 March 1971 following a nine month bloody struggle, the provisional government, under the Vice President and Acting President Syed Nazrul Islam, ordered that all laws in force on 25 March would continue. This included the Laws of Continuance Enforcement Order, 1971, which retained those same laws regarding enemy property that were promulgated prior to Independence. The following year, on 4 November 1972, the Bangladesh Parliament adopted the independence principles of nationalism, socialism, democracy, and secularism, but also The Bangladesh (Vesting of Property and Assets) Order which recognized the new government as vested with 'enemy' properties seized since the 1965 War and stipulated that its provisions shall not be subjected to judicial review. Consequently, land owned by Hindus, their legal heirs, or family members currently residing on the property, was subject to dispossession, including by force. ${ }^{16}$ The Order also led to illegal appropriations as government officials were given the power to arbitrarily designate land as enemy property, thus undermining the ownership rights of Hindus as citizens, as well as their rights to state protection.

Later, in 1975, and following the murder of Sheik Mujibir Rahman, popularly known as Bangabandhu (Friend of Bengal) and the founding father of Bangladesh, religious and ethnic identities were again challenged, especially by Bangladeshi nationalism which accompanied the ascendency of the military regimes of Zia Rahman (1975-1981) and Hossain Mohammad Ershad (1981-1990). Bangladeshi nationalism was a project aimed at purging Hindu idioms from Bengali national identification in efforts to distance the country's cultural landscape from both the Awami League and (Hindu) West Bengal. Crucially, it answered the national identity question by reframing 'we are Bengali first and Muslim second' as 'we are Muslims first and Bengalis second', recasting national belonging from an ethnic identification with Hindu West Bengal, India, to a religious identification with Pakistan. Unsurprisingly, this shift also recognized Islamist interests and political party participation, particularly of the Jaamat-i-Islami, thereby compromising the secular principle of independence. The change led first, in 1977, to the deletion from the Constitution of secularism as a state principle and, second, in 1988, to the declaration of Islam as the state religion. At play during the shift from Bengali to Bangladeshi nationalism was a rhetoric that emphasized the specter of caste Hindu domination, the tensions of partition, and the communal violence that shaped political rule in what was characterized as Hindu India (Chowdhury 2009).

The reproduction of Hindus as other was thus further entrenched by practices of cultural and social enclosure, including when, under military rule, Muslim prayer before public meetings and on television, was first promoted and then required; and again, in 1979, when Zia Rahman added 'Bismillah ar-Rahman ar-Rahim' before the Preamble of the Constitution and replaced the words 'historic struggle for national liberation' with 'historic war for national independence'. This latter move signals the shift from a liberation struggle to a nationalist project to claim sovereignty and safeguard Bangladesh from her foreign enemy, India. These changes reflected Zia's effort to elide connections between the liberation movement and those of the 1952 Language Movement that recognized struggles for a shared Bengali culture against an Urdu dominated Islamic one. To accomplish this shift, he introduced 'Islamiyat' (Islamic religious study) as compulsory from Class I-VIII, giving minority students the option of taking similar religious courses (Samad 1998) and requiring school instruction in vernacular Bangla, including at the 
university, as a way to encourage identification with Islam and Pakistan (Guhathakurta 2002). Critical to his state-making project was Zia's distinction between Bengali and Bangladeshi identity, which not only marked Hindu Bengalis and Bangladeshis as dissimilar, but also gave credence to the sense that all Hindus, those in India as well as Hindu Bengali citizens of Bangladesh, were always potential enemies of the state. Such practices reignited insecurity and fear in the everyday lives of minority populations, while also encouraging the temporary and permanent migration of Hindus to India.

\section{Contingencies of ownership and the politics of difference under democratic rule} Ershad that led, in 1991, to the first democratic elections that brought Khaleda Zia and the Bangladesh National Party (BNP) to power. Their alliance with the Jamaat-i-Islami made the victory of the BNP possible and raised, again, the specter of Islam as a defining feature of the ruling project. Ali Riaz (2003) suggests that the turn to Jamaat occurred precisely because the two leading political parties failed to secure hegemonic rule and, thus, allied with Jamaat simply for electoral expediency. Claims of expediency notwithstanding, such alliances have long-term consequences that build on Jamaat's institutionalization during military rule and continue as part of a process of Islamization that threatens the security of minority populations. Meghna Guhathakurta (2012) acknowledges this threat as contributing to a growing sense of alienation, while Abul Barkat and his coauthors (2008) show that it led to ongoing Hindu forced, or 'last resort', migration. Property Act, 2001 (Act No. 16 of 2001) which stipulated that previously confiscated lands should be returned to their original Hindu owners. However, the Act referred only to properties vested prior to February 1969, while ignoring properties confiscated afterwards that were likely in the hands of government officials or miscreants, and often confiscated illegally. It also excluded land that was no longer in government hands or currently used by or leased to an authorized person. Thus, despite this initial sense of promise, these and other restrictions of the Act failed to offer claimants access to the return of land that they or their families owned.

Khaleda Zia's return to power further diluted the Restoration Act by removing time limits on the government's responsibility to enforce the return of property. Emphasizing the role of political power in illegal land appropriations, Barkat (2000) calculates that 44.2 percent of vested property was appropriated by members of the AL, 31.7 percent by the BNP, 5.8 percent by Ershad's Jatiya Party, 4.8 percent by Jamaat-e-Islami, and 13.5 percent by others. And, under BNP rule (2001 to 2006) an additional eight percent of the incidents of land encroachment were added to the more than 2 million acres of land, or 45 percent of all land owned by Hindus taken before this period (ASK 2006).

Also consequential for the social and economic security of Bangladeshi Hindus are communal relations in India. For example, soon after the elections, the country witnessed the 1992 destruction of the Babri Masjid by Hindu fundamentalists that led to the death of more than 2000 people, not only in Ayodhya, Uttar Pradesh, but also in a number of cities across the country. The Gujarat riots that followed a decade later, in 2002, resulted in the 
death of more than 2000 Muslims and displaced hundreds more. In each case, there were retaliatory attacks on Hindu people and property in Bangladesh with little government intervention to stop them, which further deprived Hindus of a sense of social security and access to adjudication.

The result of such failures of government has been a growing sense of alienation among those against whom violence can be justified by routine practices of rule that reflexively render them different, unworthy, and devalued. Such practices recall women who met the wrath of witch-hunters as they resisted usurpations in their struggle for more egalitarian gender relations, leading to, among other acts of violence, 'the murder of the accused and the confiscation of their properties' (Federici 2008: 21). Reproducing such difference, in other words, is a process of ongoing social enclosure-othering, devaluation, and exclusion-that entail public discourse that constructs the other as enemy and makes subjects of presumed citizens. Critical to this account are the claims that such appropriations are carried out in the name of protecting the Muslim majority and securing their rights as citizens of the state.

31 Such practices build on demonizing narratives against Hindus that once initiated gain currency as they circulate in the press, in literature, and in memoirs, as well as in private discussion and rumor within families and communities (Guhathakurta 2012). They are materialized in state policies that construct difference and justify differential state action that gradually alienates, marginalizes, and discriminates against Hindus. But, importantly, they include reluctance amongst Hindus to adjudicate or claim ownership rights because they fear retribution. Further, even among those with the social networks and financial resources to fight for control of their property, fear, angst, and disrespect shape processes of adjudication. Arild Ruud (1996) suggests that such practices can lead personnel, acting on behalf of state institutions, to refuse or fail to safeguard members of the Hindu community by ignoring illegal practices, including violence committed against them, or to defer responsibility when requests for fairness or recompense have been made. Benkin (2009: 80) suggests these actions can lead to legalized oppression, even ethnic cleansing. Another way to make the same point, indicating the recursive character of policy reforms and subjection, is that the Hindu minority community in majoritarian Bangladesh is deemed to require destruction of their power through 'extermination', an experience that also characterizes relations in the Chittagong Hill Tracts (Federici 2004: 63, Introduction to this volume).

Importantly, these relations of social enclosure and, in the extreme, extermination, both accompany and justify forms of expropriation that recast social life, turning peasants into proletarians or worse, since today, processes of land appropriation go hand-in-hand with the withdrawal of state support for the rural poor. For all Hindus, but particularly the land-poor, this leads to lives that are increasingly precarious, as usurpation through legal and contractual transgressions are secured, as a matter of state, in a context that includes the privatization of public resources and market-driven solutions to social issues. Differential access to new resources can be legitimated on the basis of Hindu difference/ enmity and claimed in the name of national security. Finally, in struggles over land claims and illegal expropriations by government personnel, aligning the management of vested property claims with primarily rural and town administrators turns a blind eye to the state's complicity with elite expropriators in ways that further limit the possibilities for redress. 


\section{The current conjuncture: amending the VPA}

$$
\text { to rising expectations among those seeking redress for the VPA. On } 6 \text { November 2008, the }
$$
High Court division of the Supreme Court challenged the Enemy Property (Continuance of Emergency Provision) (Repeal) Act of 1974, arguing that it contradicts the fundamental rights and charter of the Bangladesh Declaration of Independence. The Government followed with the Vested Property Repeal (Amendment) Act, 2011, which was amended again in 2012 and 2013. ${ }^{17}$ Each of these amended Acts raised expectations among Bangladeshi Hindu citizens, even as pre-election violence in 2013, including demolition of Hindu temples and failure of the government to protect those targeted, dashed their hopes for redress.

But this time, frustration with the failure of the AL to implement the return of seized property led to a critical public discussion organized by nine rights organizations and citizen groups ${ }^{18}$ which argued that the amended Vested Property Repeal (Amendment) Act of 2013 'is part of a plot by corrupt land officials to prolong the return of "vested property"'. ${ }^{19}$ Under current law, not only do 'corrupt officials' illegally enlist land as vested property, but they also publish gazettes on newly identified lands that create opportunities for the continual harassment of Hindu landowners by district officers. Moreover, Subrata Chowdhury of Arpito Sampatti Ain Protirodh Andolon (ASAPA) suggests that the move to allow the publication of supplementary gazettes, expand the list of properties, and extend 'the timeline for publishing the supplementary gazettes is an attempt to prolong the crisis of vested property laws in a new form' (Jahangir 2013).

Identifying the complicity of 'corrupt officials' was a central concern. As Kazal Debnath of the Bangladesh Hindu Buddha Christian Oikya Parishad (HBCOP) makes evident, each of the 16 or 17 documents required under the law to file a complaint entail bribes to officials. Barkat et al. (2008) similarly argued in reference to an earlier period that 'the notorious ordinance of 1965 began the vesting of property of religious minorities who were temporarily forced out of the country, but corrupt land officials benefit from refusing to enforce the Supreme Court verdict of 23 March 1974 that declared the Enemy Property Order 1965 dead' (Guhathakurta 2002: 82). The new amendment similarly advantages land officials who have been involved in vesting for a long period, allowing them 300 more days to list vested properties while offering the plaintiffs only 30 days to file their complaints (Jahangir 2013).

Sadly, but unsurprisingly, the amended Act has yet to be implemented, further contributing to Hindu insecurity and affecting forms of adaptation and avoidance, including everyday linguistic choices that people make when in public. As Guhathakurta explains, 'Muslim terminology [is often chosen] [...] in order to disguise their (Hindu) difference of identity in public; either to cause less hassle or simply to avoid eyebrows being raised' (2002: 82). Such relations of sociality are constitutive of the vulnerabilities of those who are likely to fall prey to potential land expropriation and the poor who fear reprisal should they complain or challenge the behavior of Muslim elites or government officials.

37 Middle class Hindus express similar feelings of vulnerability, although they are more likely to assert their rights and use legal resources to secure family property. As one key middle class informant lamented, 'I have the resources and the connections to fight for

South Asia Multidisciplinary Academic Journal, 13 | 2016 
my property, but it takes a lot of money and connections to do so... we always have to worry... we don't often win' (Feldman 2014). Thus, despite their status as members of the middle class, living with the continual threat of land grabbing means that many Hindus choose not to seek redress:

This is the story of 23 acres of land in Faridpur District: The original owners went to India during the Indo-Pak War, the land was recorded as vested property but was actually taken by three men, Khaleque, Rashid, and Hakim. Khaleque 'prepared' false documents for part of the land, ignoring the fact that vested property cannot be sold, and subsequently sold a portion of it to Muktar and Ismail. Ismail sold 'his' land to Hafizur. Yet, what is also clear is that a nephew of the original owner still resides in the area, a 50-year-old village physician (Feldman 2014).

While this window on the social life of land ownership illuminates the violence and illegal transfers associated with the VPA, it fails to address what these processes mean for Hindu owners. In this case, Mr. Das does not have living relatives in the area; nor did his uncle formally transfer the land to him or his family. However, any legal successor to the real owner is eligible to petition for the property if they can produce a legal succession certificate. Yet, as a man of some means, he has not petitioned for his land and makes plain why he has not done so: 'The court may issue an order in favour of me, but if I would like to take possession, they (those currently on the land) will kill me. Moreover, I [...] am in doubt whether I would be able to secure my own properties from the grabbers' (Feldman 2013). This and numerous similar stories reveal the costs of being a Bangladeshi Hindu, particularly regarding everyday social behavior and access to resources and rights.

In other instances, a person's village status changes when their land is vested. To summarize a finding from Barkat et al. (2008: 133-37): As a school teacher, Mr. Debnath was a respected member of the local School Managing Committee, the local Puja Committee, the shalish (local village court), and regularly contributed to community ceremonies. However, his financial security deteriorated when he brought a legal suit against Abdul Aziz and Kalipad Ghoshal, who had grabbed his agricultural land. He first discovered that someone had claimed his property when he visited the tehsil office to pay his taxes and was told the land was recorded in the name of two others. After working with the Deputy Commissioner, he was informed that the title would be reissued in his name, but, when he went to harvest his crop, a violent exchange ensued with Aziz's gang. A shalish followed only to confirm that the land belonged to Aziz, a prominent BNP businessman in the community.

In addition to revealing the Bangladeshi Hindu's own cautious behavior and routine disrespect from others, Barkat et al. (2008) show how usurpers both threaten Hindu landowners with eviction and harass young girls ('eve-teasing') in ways that lead families to stop sending girls to school simply to avoid harassment. Others note that in some communities, every male has been beaten at least once. But, as community members argue, most disturbing is the lack of response to such acts of violence by authorities who implicitly condone continued attacks and harassment. As Shuruz (2004) similarly notes, the desperation of a Gopalpur villager is evident as she recounts that the brutality of crimes committed this year was greater than the brutality committed by this same group in last year's attack: 'In the past, women were spared, but now some are even forcefully disrobed... Yet no officer from the police station or administration [...] showed up to 'assure our security', except after the news of it hit the press that the apathetic administration received a stirring.' Another villager recalls how, after the demolition of 
the Babri Mosque in India, a different cremation ground was usurped by this same group: 'It is a vicious, manmade cycle.' These experiences highlight the reproduction of senses of insecurity and fear in a context where perpetrators of local, community-based tensions, threats, and outbursts against Hindus do not face government redress and, in some instances, even have their actions condoned by state authorities.

In a final example, Mr. Das, a Hindu and member of the Land Ministry who accompanied me on a drive to a peri-urban area of Dhaka, made quite evident that the region, once the vegetable basket of the city, was now a major site for industrial and export production. On the drive, I queried Mr. Das about the dramatic transformation of this once rural countryside. But, he met every effort I made to casually discuss this dramatic change in the landscape with a variant of 'I cannot really discuss land matters since they are a matter of national security.' And when, over tea, and in the company of an Upazilla officer, I shared my experience of having been in the area 15 years earlier, and now was surprized at how quickly Bangladesh was being urbanized, Mr. Das quickly intervened, making it clear that his junior officer was not permitted to comment. Even when talking about the recent amendments to the Vested Property Act, and whether and how it was affecting his office-more work and a backlog of cases-Mr. Das quickly cut the conversation short, saying that they had no information, since the gazetteers listing vested properties had yet to be released. In sharing my experience with other researchers, policy makers, and NGO members, my interpretation of the lack of transparency and obfuscation on the part of government representatives was confirmed (Feldman 2013).

42 As land seizures continue, including the taking of buildings located in provincial towns where they are increasingly valued, even those with resources and connections to toplevel administrators may be unable to ward off property grabs. Under these conditions, and without holding accountable those who use their power and are complicit in land grabbing, there is little guarantee that Hindu owners will ever be able to secure their rights to property and full citizenship. What these examples also show is that dispossession depends on the expropriation of property, the governance structures that legitimate the practice, and the constitution of fear among those who might have legal claims to the property. One can only wonder whether the tease of policy change, and accompanying claims of opportunities for redress, will actually be able to deliver on the promise to stop illegal land grabbing. And one can only wonder if patterns of othering, engendering fear among Hindus marked as threats to national security, will also be undermined, particularly under current regimes that claim to be, and are recognized internationally as, democratic formations.

\section{Conclusion}

43 In this paper, I have sought to explain the loss of as much as 75 percent of religious minority property confiscated and justified under the VPA (Choudhury 2009). Not only did the Pakistani state claim rights to Hindu land for government and public use prior to Independence, but the most concentrated appropriations, often taken illegally, occurred immediately following independence during the first AL and BNP governments (19721975; 1976-1980) (Choudhury 2009). These expropriations were followed by a period of unregulated land grabs during continued military rule (1980-1990) and, again, under the democratically elected formations of the Bangladesh National Party (1991-1996; 2006- 
2008) and the Awami League (1996-2000; 2009-2013; 2014-). Despite these appropriations, aspirations for Hindu recognition, under Sheik Hasina and the AL, and fear of Hindu hostility under Khaleda Zia and the BNP, characterize the experiences of Hindu citizens. The fear of retribution by Hindu property owners, and the class and regional dispersion of the Hindu population have contributed to limited resistance but also to a sense that survival may sometimes depend on hiding one's sense of self. In Arjun Appadurai's words, identifications can become

unstable, indeterminate, and socially volatile, [and] a means of satisfying one's sense of one's categorical self. [...] Uncertainty about identification and violence can lead to actions, reactions, complicities, and anticipations that multiply the preexisting uncertainty about labels. Together, these forms of uncertainty call for the worst kind of certainty: dead certainty (Appadurai 1998: 922-23).

I have argued that focusing on the Vested Property Act and its various iterations offers an optic through which to explain relations of dispossession and subjection that simultaneously constitute the logic and the institutionalization of the Act. In so doing, I offer four critical interventions to contemporary discussions of land grabbing. First is the need to explore further everyday forms of expropriation as constitutive of contemporary neoliberal practice. By exploring neoliberal practice, I emphasize the continued valorization of accumulation for some, on the one hand, and wage labour, rather than subsistence production, on the other. To realize processes of accumulation, I lend support to what Gardner and Gerharz (Introduction to this volume) refer to as 'crony capitalism', a form of hyper development enabled by the state's neoliberal 'open door' policies. Second, I argue that the material and structural aspects of land grabbing should be understood as mutually constitutive processes that depend on both cultural enclosures and relations of subjection. This means that cultural enclosures and relations of subjection are not merely effects of legal and illegal land grabs; rather, they depend on such relations of rule for their enactment.

To understand the institutionalization of land grabbing, in other words, requires attention to the ways in which relations of rule minoritize, subjugate, and create fear among selected members of a social formation and how such fear is deployed to legitimize their subjugation. In some instances, they enable removal, extermination, looting, burning, eve-teasing, and other forms of violence, or what Appadurai (1998) perceptively reveals in his discussion as ethnic violence in the era of globalization. The third point, then, is that while all vulnerable people are potential targets of land grabbing, only the construction of particular others from whom such grabs can be legitimated will secure popular support and not spark general unrest. I have also emphasized the criticality of historically specific relations of dispossession as the basis for understanding land appropriations and the need to tether forms of rule to the expropriation of people and communities from their property as well as economic and social security. Finally, in showcasing these points I have emphasized the criticality of viewing land grabs as an ongoing process that is reproduced under changing circumstances, where tensions of property ownership are not claimed once and for all, but rather, are constituted through continual, if changing, processes of rule and the creation of difference. 


\section{BIBLIOGRAPHY}

Abrams, Philip (1988) 'Notes on the Difficulty of Studying the State', Journal of Historical Sociology, $1(1)$, pp. 58-89.

Adnan, Shapan (2013) 'Land Grabs and Primitive Accumulation in Deltaic Bangladesh: Interactions between Neoliberal Globalization, State Interventions, Power Relations, and Peasant Resistance', Journal of Peasant Studies, 40(1), pp. 87-128.

Ain o Salish, Kendra (2006) 'Rights of Religious Minorities', Bangladesh Policy Brief, Fall, URL: http://www.askbd.org/Hr06/Minorities.htm.

Appadurai, Arjun (1996) Modernity at Large: Cultural Dimensions of Globalization. Minneapolis: University of Minnesota Press.

Appadurai, Arjun (1998) 'Dead Certainty: Ethnic Violence in the Era of Globalization', Development and Change, 29, pp. 905-25.

Barkat, Abul (2000) An Inquiry into Causes and Consequences of Deprivation of Hindu Minorities in Bangladesh through the Vested Property Act: Framework for a Realistic Solution, Dhaka, Bangladesh: PRIP Trust.

Barkat, Abul; Zaman, Shafique uz; Khan, Md. Shahnewaz; Poddar, Avijit; Hoque, Saiful; Uddin, M. Taher (2008) Deprivation of Hindu Minority in Bangladesh: Living with Vested Property, Dhaka: Pathak Shamabesh.

Barkat, Abul; Zaman, Shafique uz; Rahman, Azizur; Poddar, Avijit (1997) Political Economy of the Vested Property Act in Rural Bangladesh, Dhaka, Bangladesh: Association for Land Reform and Development.

Beachler, Donald (2007) 'The Politics of Genocide Scholarship: The Case of Bangladesh', Patterns of Prejudice, 41(5), pp. 467-92.

Benkin, Richard L. (2009) 'Ethnic Cleansing in Bangladesh', Himalayan and Central Asian Studies, 13 (4), pp. 79-94.

Bonefeld, Werner (2001) 'The Permanence of Primitive Accumulation: Commodity Fetishism and Social Constitution', The Commoner, September.

Charusheela, S. (2011) 'Response: History, Historiography, and Communal Subjectivity', Rethinking Marxism: A Journal of Economics, Culture \& Society, 23(3), pp. 322-27.

Choudhury, Salah Uddin Shoaib (2009) 'Vested Property Act Being Scrapped in Bangladesh', September 10, URL: http://www.weeklyblitz.net/273/vested-property-act-being-scrapped-inbangladesh [accessed 31 October 2010].

Chowdhury, Iftekhar Uddin (2009) 'Caste Based Discrimination in South Asia: A Study of Bangladesh', Working Paper Series, Volume III, No. 7, New Delhi: Indian Institute of Dalit Studies.

De Angelis, Massimo (2001) 'Marx and Primitive Accumulation: The Continuous Character of Capital's “Enclosures"', The Commoner, September.

De Angelis, Massimo (2004) 'Separating the Doing and the Deed: Capital and the Continuous Character of Enclosures', Historical Materialism, 12(2), pp. 57-87. 
Federici, Silvia (2004) 'Witch-Hunting, Globalization, and Feminist Solidarity in Africa Today', Journal of International Women's Studies, 10(1), pp. 21-35.

Federici, Silvia (2004) Caliban and the Witch: Women, the Body, and Primitive Accumulation, Brooklyn (New York): Autonomedia.

Guhathakurta, Meghna (2012) 'Amidst the Winds of Change: The Hindu Minority in Bangladesh', South Asian History and Culture, 3(2), pp. 288-301.

Guhathakurta, Meghna (2002) 'Communal Politics in South Asia and the Hindus of Bangladesh', in Monirul Hasan \& Lipi Ghosh (eds.), Religious Minorities in South Asia: Selected Essays on Post-Colonial Situations, New Delhi: MANAK Publications Pvt. Ltd., pp. 70-87.

Hall, Derek (2013) 'Primitive Accumulation, Accumulation by Dispossession and the Global Land Grab', Third World Quarterly, 34(9), pp. 1582-604.

Harvey, David (2003) The New Imperialism, Oxford: Oxford University Press.

Jahangir (2013) 'The Bangladeshi parliament has passed a landmark bill that will enable the return of property seized from the country's Hindu minority: 'Vested Property Repeal (Amendment) Act 2013 part of plot', BBC News, 14 June.

Jalal, Ayesha (1995) ‘Conjuring Pakistan: History as Official Imagining', International Journal of Middle East Studies, 27(1), pp. 73-89.

Jinnah, Mohammed Ali (2004) Quaid-i-Azam Mohammad Ali Jinnah: Speeches as Governor-General of Pakistan, 1947-1948, Lahore: Sang-i-Meel Publications.

Lambert, Richard D. (1950) 'Religion, Economics, and Violence in Bengal: Background of the Minorities Agreement', Middle East Journal, 4(3), pp. 307-28.

Lintner, Bertil (2003) 'The Plights of Ethnic and Religious Minorities and the Rise of Islamic Extremism in Bangladesh', Asia Pacific Media Services, 2 February, URL: www.asiapacificms.com.

Marx, Karl (1983) Capital, Volume I, Chapters 26-33, London: Lawrence \& Wishart.

Midnight Notes Collective (2001) 'The New Enclosures', The Commoner, September, URL: http:// www.commoner.org.uk/02midnight.pdf.

Mohsin, Amena (2004), 'Religion, Politics and Security: The Case of Bangladesh', in Satu P. Limaye, Robert G. Wirsing \& Mohan Malik (eds.), Religious Radicalism and Security in South Asia, Hawaii: Asia Pacific Center for Security Studies. pp. 467-88.

Pertev, Rasit (2009) 'Economics of Corruption by Democracy', Available at Social Science Research Network, URL: http://ssrn.com/abstract=1467900.

Riaz, Ali (2003) "“God Willing”: The Politics and Ideology of Islamism in Bangladesh', Comparative Studies of South Asia, Africa and the Middle East, 23(1-2), pp. 301-20.

Ruud, Arild Engelsen (1996) 'Contradictions and Ambivalence in the Hindu Nationalist Discourse in West Bengal', in Stein Tonnesson \& Hans Antlov (eds.), Asian Forms of the Nation, Richmond: Routledge Curzon, pp. 151-80.

Samad, Saleem (1998) ‘State of Minorities in Bangladesh: From Secular to Islamic Hegemony’, URL: www.sacw.net [accessed 31 October 2010].

Schechtman, Joseph B. (1951) ‘Evacuee Property in India and Pakistan', Pacific Affairs, 24(4), pp. 406-13.

Shafi, Salma A. (2007) 'Land and Tenure Security and Land Administration in Bangladesh', Final Report, Dhaka: LGED, UNDP \& UN-Habitat Project BGD/98/006, June. 
Shuruz, Mominul Islam (2004) 'Caught in the Land-grabber's Grasp', Star Weekend Magazine, 4, 24, December 10.

Trivedi, Rabindranath (2007) 'The Legacy of Enemy Turned Vested Property Act in Bangladesh', Asian Tribune, 11, 632, 29 May.

van Schendel, Willem (2009) A History of Bangladesh, Cambridge: Cambridge University Press.

Verdery, Katherine (1994) 'Ethnicity, Nationalism, and State-making: Ethnic Groups and Boundaries: Past and Future,' in Hans Vermeulen \& Cora Govers (eds.), The Anthropology of Ethnicity: Beyond 'Ethnic Groups and Boundaries', Amsterdam: Het Spinhuis, pp. 33-58.

Vermeulen, Hans; Govers, Cora (eds.) (1994) The Anthropology of Ethnicity: Beyond 'Ethnic Groups and Boundaries', Amsterdam: Het Spinhuis.

\section{NOTES}

1. Under the "Defense of Pakistan Rules" (DPR), the Government of Pakistan passed the Enemy Property (Custody and Regulation) Order II of 1965 that was reconfirmed as the Enemy Property Ordinance, 1969 after the Indo-Pakistan war. This was followed by the East Pakistan Rule 161, the East Pakistan Enemy Property (Lands and Building) Administration and Disposal Order, which continued after the independence of Bangladesh. While the practice remained the same, the name formally changed under the Vested and Non-resident Property (Administration) Act (Act XLVI) of 1974.

2. Included here is theft by private interests and the state's failure to intervene to protect the property rights of Hindu citizens.

3. The 'ungodly secularists' include the Hindu population who were especially targeted during the war. While other groups in Bangladesh have been marginalized, particularly the Bihari and tribal communities, it is Hindu property that is the target of the Vested Property Act and the sole focus of this paper.

4. See, for example, the contributions of Bonefeld 2001, De Angelis 2001, 2004, Hall 2013, Harvey 2003, Marx 1983, Midnight Notes Collective 2001; and, for a Bangladesh example, see Adnan 2013.

5. Unlike previously, when low-wage non-farm employment was a growing sector, today illegal and legal seizures are more likely to generate precarious lives and livelihoods with limited opportunities for work, even at below-subsistence levels. In this context, NGO and other parastatal institutions have helped the transition to market dependence, a hallmark of neoliberalism, which is realized through credit/debt schemes and training programs assumed to help generate income for the rural and increasingly the urban poor.

6. Hall (2013: 1584) supports this claim in noting that 'only some definitions [of primitive accumulation and accumulation by dispossession] mention the actors involved (these include capital, states, state-owned enterprises and non-profit entities)'. Yet in his 2011 work, he too fails to acknowledge the dispossessed as actors, whether through organized and collective resistance or as individual or family resource owners.

7. Relations of exclusion are more provocatively explored as relations of inclusion to emphasize the fact that experiences of exclusion and the protections of state are particular characteristics of belonging, however unequal. From this perspective, there is no position of social exclusion, only a lack of rights and access to resources as a condition of unequal inclusion.

8. See, for example, the collection by Vermeulen \& Govers (1994), particularly the essays by Barth, and Verdery (1994) for her focus on political economy.

9. It is impossible to explore these processes of ethnicization and minoritization here. It will suffice to offer the critical question posed by Appadurai (1996: 41): 'are we in the midst of a vast 
worldwide Malthusian correction, which works through the idioms of minoritization and ethnicization but is functionally geared to preparing the world for the winners of globalization, minus the inconvenient noise of its losers?'

10. The insecurity this created for Hindu citizens during this period of Pakistani rule led to one of the largest migrations of Pakistani Hindus to West Bengal, India.

11. The Language movement remains significant for Bangladesh's national narrative and is celebrated each year on 21 February, Ekushy.

12. Both H.S. Suhrawardy and Mujib-ur-Rahman would be central to the movement for regional autonomy and, subsequently, to the independence movement.

13. This was followed by The East Bengal Evacuees (Administration of Property) Act (VIII of 1949), The East Bengal Evacuees (Restoration of Possession) Act (XXII of 1951), The East Bengal Evacuees (Administration of Immovable Property) Act (XXIV of 1951), The East Bengal Prevention of Transfer of Property and Removal of Documents and Records Act of 1952, and The Pakistan (Administration of Evacuees Property) Act (XII of 1957). In the context of the Indo-Pakistan War the following acts were passed: The East Pakistan Disturbed Persons (Rehabilitation) Ordinance (No 1 of 1964), The Defense of Pakistan Ordinance (No. XXIII of 6 September 1965), The Defense of Pakistan Rules of 1965, The Enemy Property (Custody and Registration) Order of 1965, The East Pakistan Enemy Property (Lands and Buildings Administration and Disposal Order of 1966), and The Enemy Property (Continuance of Emergency Provision) Ordinance No. 1 of 1969.

14. Hindu citizens of East Pakistan did resist some of these initiatives, but others chose to participate in the Constituent Assembly and work alongside Muslim leaders. Class differences among Hindus may also have limited mass opposition-many were part of the educated elite and among university faculty and civil servants, while others were dispersed throughout the country and among poor farmers and fishers.

15. A great deal has been written on Hindu families who have left East Pakistan/Bangladesh for West Bengal, but far less has been written about those who chose to remain in their country of birth.

16. While the Order included the seizure of so-called abandoned property from ethnic Biharis residing in Bangladesh prior to 1971, Hindus, who were its immediate target, owned the majority of appropriated land.

17. The Vested Properties Return (Amendment) Bill, 2011, enables Hindus to reclaim their property taken by the government or by individuals. The 2013 Amendment allows the government to publish gazettes on new vested properties and identifies two property schedules, one for land under the district commissioner and the other for land illegally occupied by individuals.

18. The nine co-organisers include Ain o Salish Kendro, Bangladesh Hindu Buddha Christian Oikya Parishad (BHBCOP), Nijera Kori, Association for Land Reform and Development (ALRD), Arpito Sampatti Ain Protirodh Andolon (ASAPA), Bangladesh Puja Udjapon Parishad, Bangladesh Legal Aid Services Trust (BLAST), Sammilito Samajik Andolon, and Human Development Research Centre (HDRC).

19. http://www.dhakatribune.com/law-amp-rights/2013/oct/09/js-passes-vested-property-actamendment-bill\#sthash.CWwrmAXw.dpuf. 


\section{ABSTRACTS}

Constructing religious difference as a national security threat, the Vested Property Act, whose legacy dates from the period of East Pakistan, marks Bangladeshi Hindus as citizens whose allegiance to the country is always suspect. This paper explores the social production of Hindu difference through legal claims to the right to private property. I draw on shifting policy reforms to show how land rights and the control of private property, embedded in historical, social, political, and cultural relations, shape the security of people and their subjectivity. I argue that constructions of Hindu identity are marked by particular relations of social inclusion that are consequential for enacting rights claims in the interests of private accumulation.

INDEX

Keywords: dispossession, land grab, subjection, law, social rights, Bangladesh

\section{AUTHOR}

\section{SHELLEY FELDMAN}

Binghamton University (USA) 